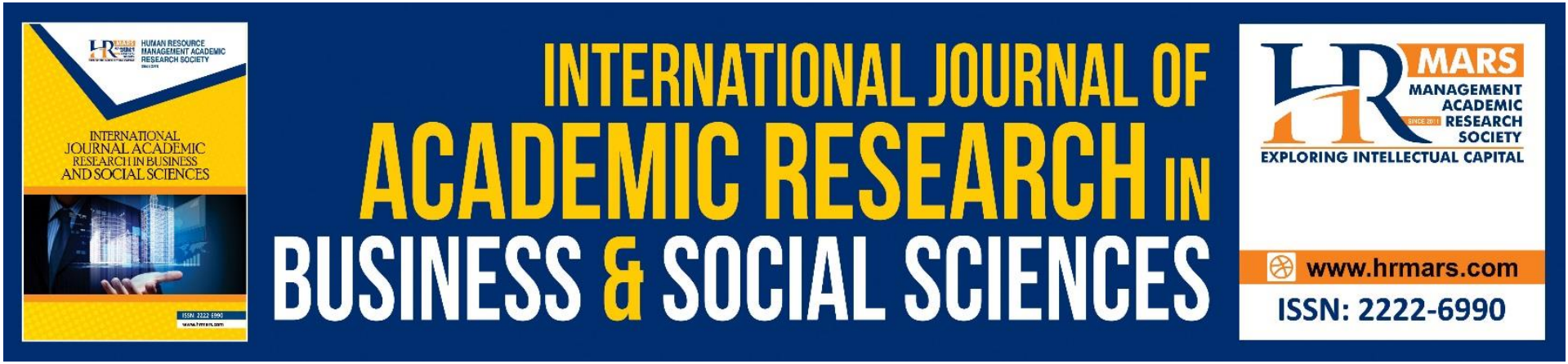

\title{
Influence of Procurement Ethics on the Performance of Devolved Systems of Governments in Kenya
}

Mary Andika, Mike Iravo, Noor Ismael

To Link this Article: http://dx.doi.org/10.6007/IJARBSS/v11-i1/8564

DOI:10.6007/IJARBSS/v11-i1/8564

Received: 11 December 2020, Revised: 01 January 2021, Accepted: 15 January 2021

Published Online: 29 January 2021

In-Text Citation: (Andika et al., 2021)

To Cite this Article: Andika, M., Iravo, M., \& Ismael, N. (2021). Influence of Procurement Ethics on the Performance of Devolved Systems of Governments in Kenya. International Journal of Academic Research in Business and Social Sciences, 11(1), 690-699.

Copyright: (c) 2021 The Author(s)

Published by Human Resource Management Academic Research Society (www.hrmars.com)

This article is published under the Creative Commons Attribution (CC BY 4.0) license. Anyone may reproduce, distribute, translate and create derivative works of this article (for both commercial and non-commercial purposes), subject to full attribution to the original publication and authors. The full terms of this license may be seen

at: http://creativecommons.org/licences/by/4.0/legalcode

Vol. 11, No. 1, 2021, Pg. 690 - 699

http://hrmars.com/index.php/pages/detail/IJARBSS

JOURNAL HOMEPAGE

Full Terms \& Conditions of access and use can be found at http://hrmars.com/index.php/pages/detail/publication-ethics 


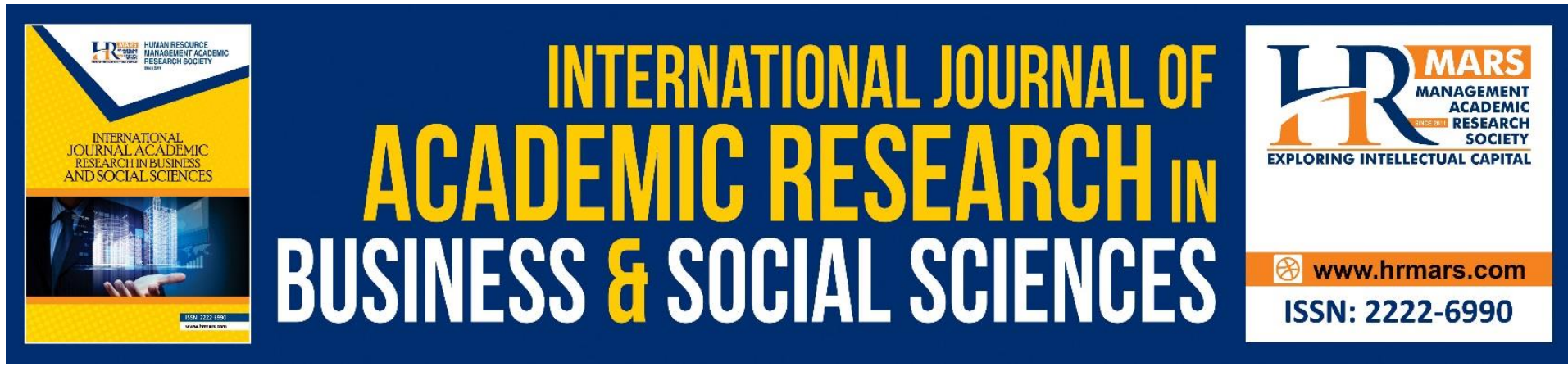

\title{
Influence of Procurement Ethics on the Performance of Devolved Systems of Governments in Kenya
}

\author{
Mary Andika (PhD Candidate) \\ Department of Procurement and Logistics, Jomo Kenyatta University of Agriculture and \\ Technology, Kenya

\section{Mike Iravo} \\ Department of Entrepreneurship, Technology, Leadership and Management, Jomo Kenyatta \\ University of Agriculture and Technology, Kenya
}

\section{Noor Ismael}

Department of Procurement and Logistics, Jomo Kenyatta University of Agriculture and

Technology, Kenya

\begin{abstract}
Purpose -The purpose of this paper is to examine the influence of procurement ethics on the performance of devolved systems of governments in Kenya.

Design/Methodology/Approach- A cross-sectional approach is adopted with primary data collected. The data yielded a response rate of 229 from 10 devolved systems of governments Kenya which were drawn mainly from supply chain and finance departments. The data collected was put through rigorous statistical analysis to test content validity as well as reliability. Further, simple linear regression model was used to test relationships between procurement ethics and the performance of devolved systems of governments in Kenya.

Findings- The finding proposes that a successful execution of procurement ethics increases the performance of devolved systems of governments through efficiency management of public resources, fair competition in bidding process and provision of all the required information in the bidding processes. Further, the study revealed that some devolved systems of governments sliced tenders to avoid appropriate procurement process.

Research limitations/implications- The study provides relevant knowledge in formulating policy framework on efficient and effective management of public procurement process in devolved systems of governments. Also, the study show that procurement ethics if properly embraced, it will increase the performance of devolved systems of governments but not all procurement ethics practices are covered in the study and therefore a similar study can done in different sector to validate the findings.
\end{abstract}

Originality/Value The study provides a holistic approach in the application and use of procurement ethics for improving performance of devolved systems of governments. Also, 
the identified gaps provide future direction in research and encourage the adoption of procurement ethics as a way of instilling good morals in the devolved systems of governments.

Keywords: Procurement ethics, Performance of Devolved Systems of Governments in Kenya, Simple Regression

\section{Introduction}

Worldwide governments have been progressively outsourcing public service to the local citizens (Alonso et al., 2015). This approach has necessitated public procurement to be given special attention in governments and this has led to changes, reformation of rules and regulations to suit their needs. In addition, public entities are expected to achieve high performance standards to towards their respective citizens (Boyne \& Walker, 2010). Through public procurement, county governments in Kenya can be able to provide better provision of various services such as roads, healthcare and education (Errigde \& Mcllrory, 2002). Therefore, the county governments should adhere to public procurement and asset disposal act of 2015 for effectively managing procurement process (Barrett, 2000). Equally, public entities can consider using alternative best procurement approach to meet their needs (UK Treasury, 2013). This is because public procurement is gradually known as important in the delivery of services both in developed and developing countries (Basheka \& Bisangabasaija, 2008). World Bank (2004) indicated that public procurement represents eighteen percent $(18.42 \%)$ of the world gross domestic product (GDP) and most developed countries spend at least ten percent (10\%) of their GDP on public procurement (UNCTAD, 2009), although public procurement often creates the largest domestic market in third world countries.

In Kenya, the devolved system of government was meant to play a significant role in spurring economic growth and development in Kenya during the promulgation of the new constitution in 2010. This was to be achieved through sharing and distribution of national resources equitably and allowing public participation directly in the affairs of counties government (Kenya Constitution, 2010). Moreover, the enactment of Public Procurement and Asset Disposal Act (2015) in January 2016 was to promote openness, full disclosure and attainment of value for money in devolved county governments' expenditure.

However, devolved systems of governments have been experiencing major impediments in the execution of public procurement principles. According to audit report for financial year 2014/15 revealed that a huge chunk of the monies lost through the payment of unscrupulous workers or fictitious firms and non-existence suppliers in the devolved system of governments. Further, a study by Njeru (2015) noted that county government procurement sections and other public entities in Kenya are inefficient and lacks knowledge in the implementation of public procurement as laid down in the act. For example, in many tertiary public training institutions in Kenya lost close to Ksh.50 million annually through procurement dubious means. Kenya Institute of Supplies Management (KISM) report of 2010 and 2015 established that on annual bases, the government of Kenya losses close to Ksh. 21 billion about 9 per cent of the national budget due to inflated procurement quotations both in central and devolved system of governments. The report also revealed that majority of the devolved system of governments' procurement departments are influenced by external forces in the awarding of contracts and thereby end up compromising in the adherence of public procurement principles. Similarly, a study conducted by Ethics and Anti-Corruption Commission $(2015 ; 2016)$ noted that over $81 \%$ of respondents indicated that corruption, poor 
service delivery, tribalism, shoddy implementation of projects and embezzlement of funds are rampant in the devolved system of governments.

Although some studies have been carried out on public procurement principles such as Odhiambo and Kamau (2013) established that although less advanced countries have taken steps to change their public procurement systems, the process is still shrouded by high degree of secrecy, inefficiency, corruption and undercutting which has resulted to a huge amount of resources into wastage (Hagén \& Zeed, 2005). Ogutu and Were (2014) found that accountability, information communication and technology influence procurement process in devolved system of governments. However, non-of these studies addresses public procurement principles such as procurement ethics in county governments. Thus, the aim of this study was to fill the gaps identified above.

This paper is structured as follows. In section 2, we present how procurement ethics interacts with the performance of the devolved systems of governments from the literature reviewed. Part 3 discusses research methodology. Section 4 statistical analysis of data collected and part 5 presents the conclusions both discussion and implications.

\section{Literature Review Procurement Ethics}

Procurement ethics are generally accepted principles and rules of conduct that govern a given industry (Lysons \& Farrington, 2007). Ethics is basically a branch of philosophy which seeks to address questions about morality that is about concepts such as good and bad, right and wrong, justice and virtue (Lyson \& Farrington, 2007). Therefore, individuals acting in profession capacity should take an additional burden of ethical responsibilities. For example professional associations like Kenya Institute of Supplies Management have come up with codes of ethics that guides procurement officers both in public or private entities. These procurement professional are required to behave within the context of professional practices such as impartiality/objectivity, openness/full disclosure, confidentiality, duty to care and avoiding potential or apparent conflict of interest (Lyson \& Farrington, 2007).

Therefore, managing ethical issues is important because countries have lost resources due to unethical practices (Atkinson, 2003). This situation is worse in developing countries such as Kenya where majority of people who are holding procurement offices in county governments are not professionals. Most of these officers are hired based on ethnicity and nepotism to appease their masters.

In Kenya, Public Procurement and Asset Disposal Act of 2015 states that a procuring entity shall prepare an estimate budget for approval at the end of financial year. Also, procurement officers are required to start procuring goods and services once monies has been approved. This is done to ensure that projected started are not stalled and to enhance transparency. However despite these measures, procurement related corruption tends to be a serious problem in developing countries rather than in developed countries. For example, World Bank established that close to one million US dollars have been lost due to procurement malpractices. The most corrupt countries in world ranking in 2005 were Nigeria, Venezuela and Sri Lanka. These countries have lost resources through procurement malpractices. But countries such as Sweden, Netherlands, and Austria have enhanced public procurement systems which have contributed positively towards achievement of the economic growth. In Kenya, public procurement surrounded by scandals such National Youth Service lost about two billion Kenyan shillings, Kenya Power Lighting Company lost 30 billion Kenyan shillings, dams project close to 90 billion through procurement (EACC, 2018). According to 
Transparency International (2011), Auditor General Report (2016), and Ethics and Anticorruption commission showed that the National Police Service, the county governments are the public institution with highest number of stalled procurement related projects.

\section{Performance of Devolved Systems of Governments}

Organizational performance is regarded as final output or outcome. In public entities sound public procurement policies and principles are crucial attributes of good governance (KIPPRA, 2006; World Bank, 2002) which in turn will yield good performance. In measuring performance of public procurement performance, it is important to evaluate procurement system which should be focusing on effectiveness, where procuring entities should meet the commercial, regulatory and socio-economic goals of government in a way that is in line to the procurement requirement. Wittig (1999) established that any advancement in the public procurement system can have a direct or indirect beneficial outcome on the overall economic situation the county.

According to Richardson and Sevenesson (2018) they established that procurement performance can measured using price/cost dimension where the relationship between the standard/baseline and the actual price of the items delivered are measured. They further found out that product or quality dimensions of items of goods purchased as a key performance measuring indicator. They also revealed that efficiency of inventory flow of purchased materials and service in terms of quantity control, timely delivery of supplies are important when measuring procurement performance.

Moreover, a purchasing Magazine survey of consultants revealed that there are a number of objectives that firms pursue when employing procurement strategy. They included driving the lowest possible purchase price, identifying sources of high-quality products/services, simplifying the purchasing and supply management processes, and reducing transaction costs. In addition, a leading consulting firm reported that companies use strategies to reduce transaction costs, purchase price, purchase order processing cycle times, and to speed up the time-to-market cycles are common measurement of procurement performance (www.aberdeen.com 2003). Thus, this study will adopt lowest purchase price, high quality products/services, simplified procurement processes, procurement order processing cycle times and reduction transaction costs to measure performance of devolved of county government. This lead to the following research hypothesis;

$\mathbf{H}_{01}$ There is no relationship between procurement ethics and the performance of county governments in Kenya.

\section{Methodology}

\section{Instrument Development}

Content validity is ensured by adapting all the instruments from the existing previous researches in strategic sourcing, which are deemed to have reliable and valid scales. A fivepoint Likert scale anchored by 1 (Strongly Disagree) 5 (Strongly agree) is used to assess the degree of strategic sourcing in the opinion statements provided "kindly assess to what extent you agree or disagree with the following opinion statement'. Performance of devolved systems of governments was also measured using a five-point Likert scale of 1 (Strongly Disagree) 5(Strongly Agree) and by ticking in the box of the revenue indicators provided for the last five years. 


\section{Data Collection}

The study focused on devolved systems of governments in Kenya because few studies are featured in this sector. The study targeted logistics/supply chain/procurement managers in senior positions to answer the dropped questionnaires since they possessed sufficient knowledge regarding the overall process of procurement ethics and the performance of devolved systems of governments. After randomly selecting 229 samples of respondents, the researchers dropped the questionnaires which generated later a response rate of 229 which translated to $100 \%$.

\section{Results}

The following section contains the findings of procurement ethics and performance of devolved systems of governments in the descriptive and inferential statistics form. The respondents were asked to indicate the extent to which they agreed with procurement ethics opinion statements that are executed in the devolved systems o governments. The results of the analysis are presented in Table 4.1. From the results, it was established that majority of the devolved systems of government with a mean rate of 4.01 discourage fake competition. On collusion, majority of devolved systems of government with a mean rate of 4.37 indicated that they avoid collusion with their suppliers. Equally, the study found out that majority of the devolved systems of governments with a mean rate of 4.31 ensured that a goods received reflects the precise qualities stated in the specifications. This is actualized by well cross examining the product delivered against the sample of product was to be delivered. However, majority of devolved systems of governments with a mean of 3.14 agreed that they slice tenders to avoid appropriate procurement process. This practice of slicing tenders is against the Public Procurement and Asset Disposal act of 2015. The act states that tenders should not be sliced to appropriate procurement method.

Table 4.1: Procurement ethics descriptive statistics findings

\begin{tabular}{|c|c|c|c|c|c|c|c|}
\hline Opinion statement & SD & D & $\mathbf{N}$ & $\mathbf{A}$ & SA & $M$ & STD \\
\hline Discourage fake competition & $4.8 \%$ & $4.8 \%$ & $11.4 \%$ & $42.8 \%$ & $36.2 \%$ & 4.01 & 1.05 \\
\hline Avoid collusion with suppliers & $1.7 \%$ & $0.0 \%$ & $3.9 \%$ & $48.0 \%$ & $46.3 \%$ & 4.37 & .724 \\
\hline $\begin{array}{l}\text { Remove and arbitrariness from } \\
\text { bid evaluation process }\end{array}$ & $7.8 \%$ & $.9 \%$ & $11.0 \%$ & $34.4 \%$ & $45.9 \%$ & 4.10 & 1.142 \\
\hline $\begin{array}{l}\text { Goods and services received } \\
\text { reflect the precise qualities actual } \\
\text { delivered }\end{array}$ & $4.4 \%$ & $2.2 \%$ & $7.4 \%$ & $29.7 \%$ & $56.3 \%$ & 4.31 & 1.012 \\
\hline $\begin{array}{l}\text { Use slicing to avoid adopting the } \\
\text { appropriate procurement process }\end{array}$ & $21.0 \%$ & $12.1 \%$ & $21.0 \%$ & $24.1 \%$ & $21.9 \%$ & 3.14 & 1.437 \\
\hline
\end{tabular}

Key: $S D=$ Strongly Disagree, $D=$ Disagree, $N=$ Neutral, $A=A g r e e, S A=$ Strongly Agree, $M=$ mean, STD $=$ Standard Deviation

Additional test on simple regression was conducted to determine the influence of procurement ethics on the performance of devolved systems of governments in Kenya. The null hypothesis was:

$\mathrm{HO}_{1}$ Procurement ethics statistically does not influence the performance of devolved systems of governments in Kenya. 
The objective was tested by regressing procurement ethics on the performance of devolved systems of governments guided by the equation $Y=\beta_{0}+\beta_{1} X_{1}+\varepsilon$. From the results in Table 4.2, $\mathrm{R}^{2}$ for the regression model between procurement ethics and the performance of devolved systems of governments in Kenya was 0.517 meaning that procurement ethics explain $51.7 \%$ variation in the performance of devolved systems of governments in Kenya while the remaining variation is explained by the other factors which are not coovered in the study.

Table 4.2 Model Summary of procurement ethics

\begin{tabular}{lllll} 
Model & $R$ & R Square & Adjusted R Square & Std. Error of the Estimate \\
\hline 1 & $.747^{\text {a }}$ & .612 & .517 & .665 \\
\hline a. Predictors: (Constant), Procurement ethics Principle & \\
b. Dependent Variable: Measure of performance of devolved system of county \\
government
\end{tabular}

Further test on ANOVA, the regression model was a good fit as indicated by a significant Fstatistic $(F=30.698, p<0.05)$. See Table 4.3.

Table 4.3: ANOVA of procurement ethics principle

\begin{tabular}{llrrrrr}
\hline \multicolumn{2}{l}{ Model } & \multicolumn{2}{c}{$\begin{array}{c}\text { Sum of } \\
\text { Squares }\end{array}$} & \multicolumn{4}{c}{ Mean } \\
\hline 1 & Regression & 13.563 & & Square & \multicolumn{1}{c}{ F } & \multicolumn{1}{c}{ Sig. } \\
& Residual & 98.968 & 224 & 13.563 & 30.698 & $.000^{\text {b }}$ \\
& Total & 112.531 & 225 & .442 & & \\
\hline
\end{tabular}

a. Dependent Variable: Measure of performance of devolved system of county government

b. Predictors: (Constant), Procurement ethics Principle

The regression model obtained from the output was

Performance $=2.697+0.352$ procurement principle + error

The standardized regression coefficient for procurement ethics principle was 0.347 . This indicated that a unit increase in the procurement ethics principle would result in $34.7 \%$ increase in the performance of devolved systems of governments in Kenya. The t-statistic for the regression coefficient for procurement ethics principle was significant at $5 \%$ level of significance $(T=5.541, p<0.05)$ implying rejection of null hypothesis.See Table 4.4 . On the basis of these statistics, the study concludes that there is significant positive relationship between procurement ethics principle and performance of devolved systems of governments in Kenya. Hence, null hypothesis was rejected. 
Table 4.4 Coefficients of procurement ethics principle

\begin{tabular}{|c|c|c|c|c|c|}
\hline \multirow[b]{2}{*}{ Model } & \multicolumn{2}{|c|}{$\begin{array}{l}\text { Unstandardized } \\
\text { Coefficients }\end{array}$} & \multirow{2}{*}{$\begin{array}{c}\text { Standardized } \\
\text { Coefficients } \\
\text { Beta }\end{array}$} & \multirow[b]{2}{*}{$t$} & \multirow[b]{2}{*}{ Sig. } \\
\hline & $\mathrm{B}$ & Std. Error & & & \\
\hline 1 (Constant) & 2.697 & .261 & & 10.316 & .000 \\
\hline $\begin{array}{l}\text { Procurement ethics } \\
\text { Principle }\end{array}$ & .352 & .064 & .347 & 5.541 & .000 \\
\hline
\end{tabular}

a. Dependent Variable: Measure of performance of devolved system of county government

\section{Discussion}

\section{Theoretical Contribution}

From the results, it was established that majority of the devolved systems of government with a mean rate of 4.01 discourage fake competition. These study findings are in harmony with Lyson and Farrington (2006) that the procurement professional are required to behave within the context of professional practices such as impartiality/objectivity, openness/full disclosure, confidentiality, duty to care and avoiding potential or apparent conflict of interest. On collusion, majority of devolved systems of government with a mean rate of 4.37 indicated that they avoid collusion with their suppliers. These findings is in agreements with the Public Procurement and Asset Disposal act of 2015, that no procuring entity or person may collude or attempt to collude with the supplier or any person to make a proposal to increase the price otherwise, the person or supplier should refrain from submitting the tender, quotation or proposal. Also, the person or vendor who contravenes the regulation he should be disqualified from entering the contract or if the contract has already been entered, the contract may become voidable and debarred in future from transacting with the procuring entity. Also, the person may be prosecuted.

Equally, the study found out that majority of the devolved systems of governments with a mean rate of 4.31 ensured that a goods received reflects the precise qualities stated in the specifications. This is actualized by well cross examining the product delivered against the sample of product was to be delivered. This result is in agreement with the Public Procurement and Asset Disposal act of 2015 which states that when goods are delivered by vendors, the had hoc inspection and receiving committee should be constituted by the accounting officer. The committee will ensure that goods received are well inspected and correspond with the specifications requirements. However, majority of devolved systems of governments with a mean of 3.14 agreed that they slice tenders to avoid appropriate procurement process. This practice of slicing tenders is against the Public Procurement and Asset Disposal act of 2015. The act states that tenders should not be sliced to appropriate procurement method.

Based on thematic analysis, the respondents were asked to suggest ways in which procurement ethics principle can influence the performance of devolved system of government. The respondents' suggestions were grouped into four themes namely; fair competition, well utilization of funds, high quality goods and adherence to law.

On competition, the respondents suggested that procurement ethics can promote fair competition in bidding process. This is because procurement ethics would provide equal opportunity for vendors who are willing to participate in the bidding process and will provide all the information required in the bidding processes. Also, the respondents suggested that procurement ethics would provide devolved systems of governments in the use of public 
funds. This can be achieved through equitable sharing of resources within the devolved systems of governments and ensure funds are used for the intended purposes. Further, the responds suggested that procurement ethics would ensure good quality of goods and services are procured as per specifications and hence increase the efficiency and effectiveness in the devolved systems of governments. In addition, the respondents suggested that procurement ethic can make devolved systems of governments to adhere to rules and regulations as provided by Public Procurement and Asset Disposal act of 2015. Thus the adherence of rules and regulations would prevent devolved systems governments from legal tussles.

\section{Managerial Contribution}

The study recommends that all devolved systems of government should discouraged fake competition, collusion of suppliers to ensure that goods received reflects the precise qualities stated in the specifications. Also, the study found out that devolved systems of governments sliced tenders and therefore, the study recommends that the devolved systems of governments should not split tenders with the aim of avoiding competition. Further, the study recommends to the devolved systems of governments management to practice procurement ethics in all sphere of management in order to promote fair competition in bidding process as way of providing equal opportunity for vendors who participated in the bidding process and provided all the information required in the bidding processes. Procurement ethics would increase the efficiency of management of public resources as it was found to increase the performance of the devolved systems of governments in Kenya.

\section{Limitations and Future Research}

The study provides relevant knowledge in formulating policy framework on efficient and effective management of public procurement process in devolved systems of governments. Also, the study show that procurement ethics if properly embraced, it will increase the performance of devolved systems of governments but not all procurement ethics practices are covered in the study and therefore a similar study can done in different sector to validate the findings.

\section{References}

Atkinson, W. (2003). New buying tools present different ethical challenges. Purchasing, 132(4), 27-30.

Erridge, A., Fee, R., \& Mcllroy, J. (1999). An assessment of competitive tendering using transaction cost analysis. Public Money \& Management, 19(3), 37-42.

European Union. (2010). Authority for the supervision of Public Contracts, department of the coordination of European Union Policies. The comparative survey on the national public procurement systems across the Public Procurement Network $(P P N)$. Roma, Italy.

Eyaa, S., \& Oluka, N. (2011). Explaining non-compliance in public procurement in Uganda. International Journal of business and social science, 2(1), 11-18.

Government of Kenya. (2005), Public Procurement and Disposal Act 2005, 1st Edition, Nairobi: Government Printers.

Kenya Anti-Corruption Commission. (2007). Public Officers Integrity Survey. Nairobi: KACC Kenya Gazette Supplement No. 92. (2006) The Public Procurement and Disposal Regulations. Nairobi: Government of Kenya. 
Kenya Institute for Public Policy Research and Analysis. (2013). Kenya Economic Report . Nairobi: KIPPRA.

Lysons, K., \& Farrigton, B. (2006), Purchasing and Supply Chain Management. ( $7^{\text {th }}$ ed.). Harlow-UK: Pearson Education Limited.

Odhiambo, W., \& Kamau, P. (2003). The integration of developing countries into the world trading system. Public procurement lessons from Kenya, Tanzania and Uganda, available on http:/www.oecd.org, on 15th Dec. 2009.

Ogutu, O., \& Were, S. (2014). Perception of regulation on procurement process of devolved county governments in kenya: a case study of the county of Kajiado. Inernational Journal of Business \& Law Research, 2(1), 33-45.

World Bank. (2003). World Development Report 2003: Equity and Development, Oxford University Press, New York, NY.

World Bank. (2004). Guidelines: Procurement under IBRD Loans and IDA Credits. Washington DC: World Bank.

World Bank. (2007). World Development Report 2007: Development and the Next Generation, Oxford University Press, New York, NY. 